
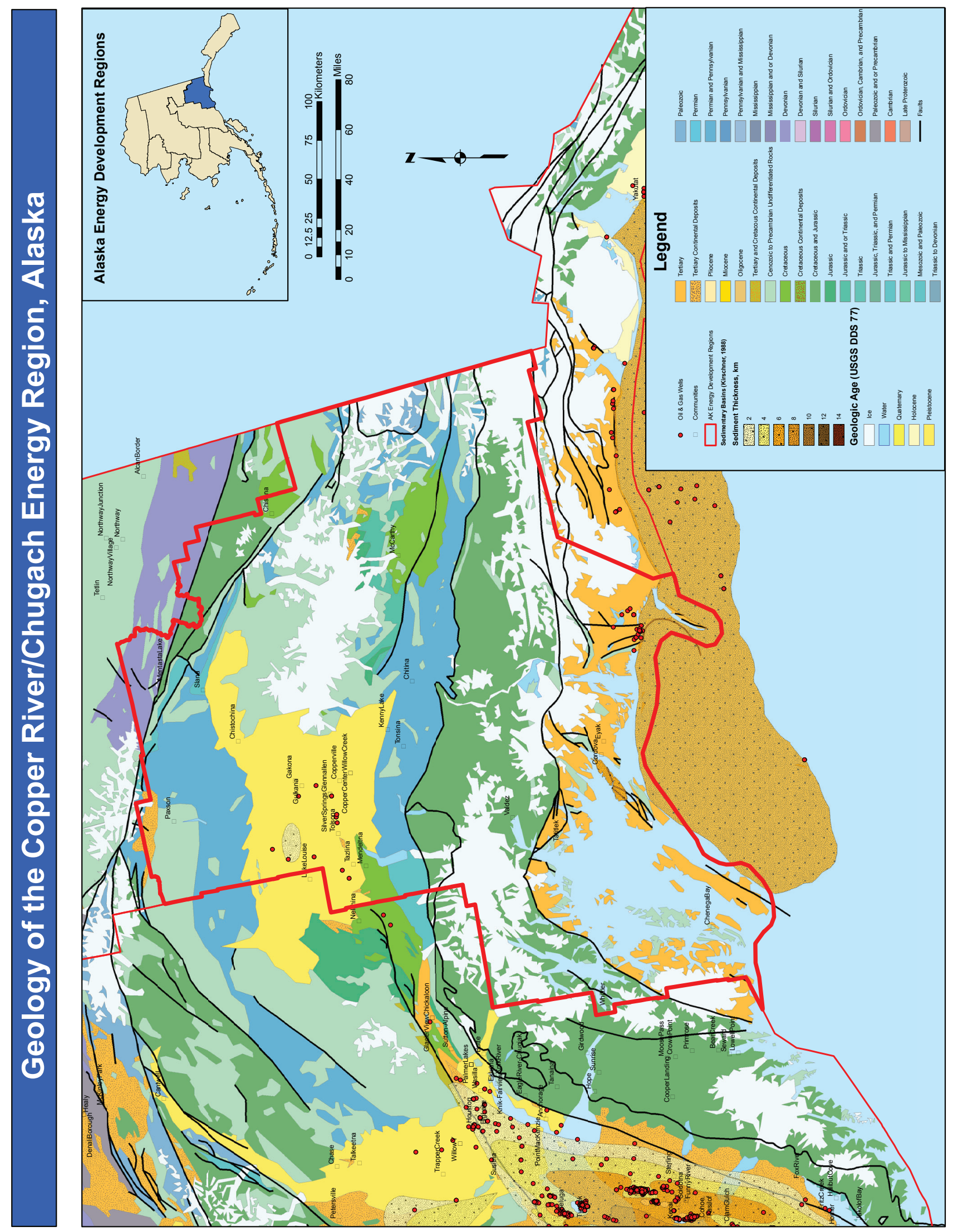



\section{SUMMARY OF FOSSIL FUEL AND GEOTHERMAL RESOURCE POTENTIAL IN THE COPPER RIVER-CHUGACH ENERGY REGION}

by Paul L. Decker, Robert J. Gillis, Ken Helmold, and Shaun Peterson

\section{INTRODUCTION}

\section{Purpose of this report}

Economic growth and stability in Alaska's rural and urban areas hinges partially, if not primarily, on the availability of affordable and sustainable energy supplies. Recent price increases in oil and gas commodities have created severe economic hardship in many areas of the state that are dependent on diesel and heating oil as their primary source of energy. All sectors of Alaska's economy rely on affordable energy sources with limited price volatility, highlighting the need to diversify the energy portfolio by developing locally available and sustainable resources that are not tied to the global market. Unfortunately, all areas are not created equal in energy accessibility; the resources available for local exploitation vary widely across the state. It is critical that funding decisions for expensive programs to reduce the dependence on diesel for heat and electricity take into account information concerning the entire suite of natural resources that exist in a given area.

This report draws from existing information to provide community and state leaders an objective summary of our current knowledge concerning the potential of locally exploitable fossil fuel and geothermal energy resources in the Copper River-Chugach Energy Region (fig. E1), one of 11 regions recognized by the Alaska Energy Authority in their Energy Plan (AEA, 2009). The potential geologically hosted energy resources considered here include exploitable coal, conventional and unconventional oil and gas, and geothermal resources. This report concludes with recommendations as to what additional data or strategies, if any, would provide the most leveraging in helping to develop new energy resources in the region.

Readers without geological training are encouraged to peruse the geologic summaries of fossil fuel resources and geothermal energy in chapter A. They provide an overview of the geologic elements that must be present in an area to economically develop coal, conventional oil and gas, unconventional oil and gas, and geothermal resources. These summaries will provide the necessary background to more fully understand the information presented in this chapter.

\section{Geographic and geologic setting}

The Copper River-Chugach Energy Region of southeastern central Alaska extends roughly 160 miles north-south between the town of Paxson and the north Pacific coastline and approximately 180 miles east-west between the Canada border and the town of Tazlina (sheet 1). Included in this region are the Wrangell, Saint Elias, and Chugach mountains and Prince William Sound. The region's largest communities are the fishing towns of Valdez, with a current population of more than 4,300 residents and Cordova with nearly 2,200 residents. Glennallen and Kenny Lake are the

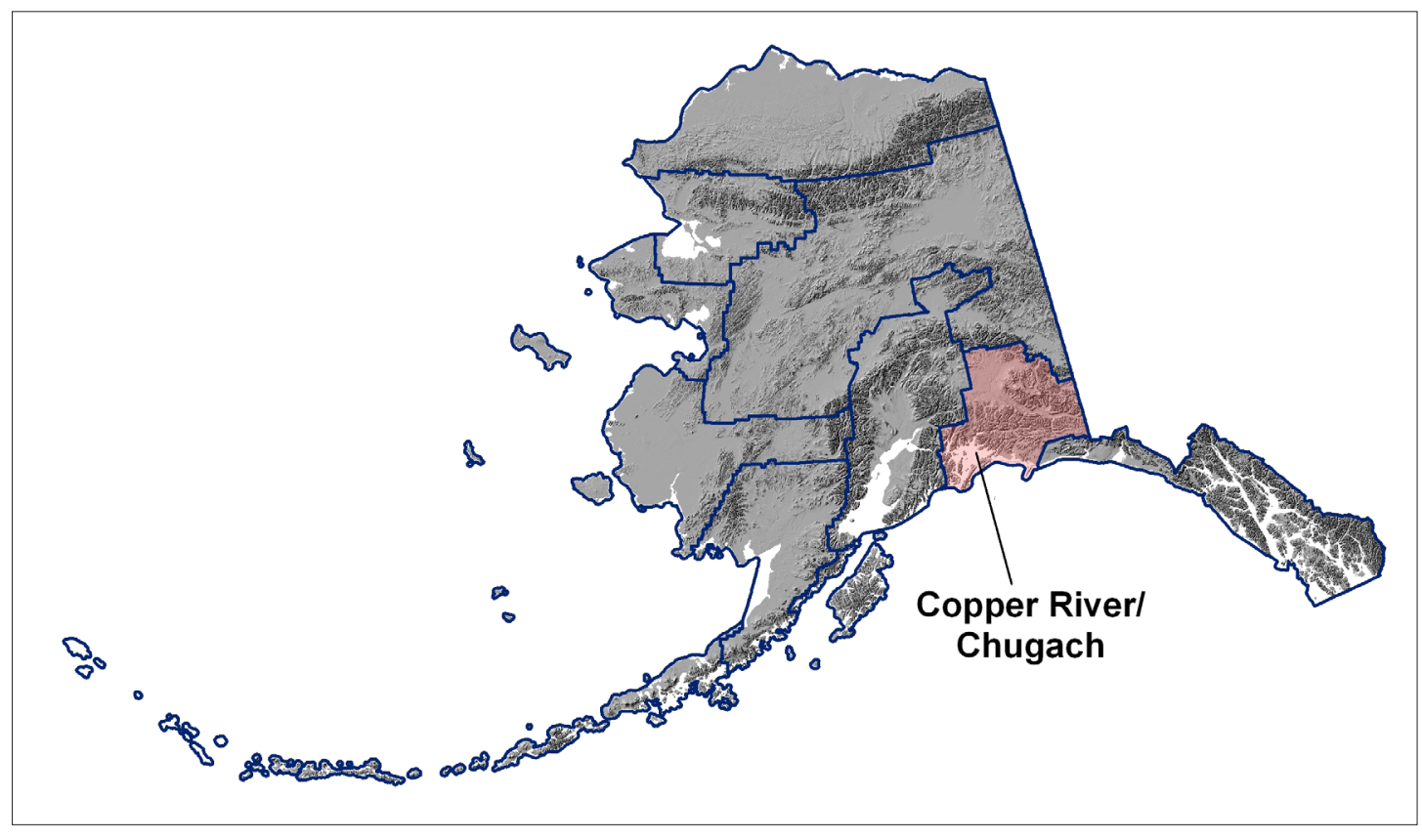

Figure E1. Location map, Copper River-Chugach Energy Region. 
largest of 15 communities with populations of 100-500 residents. Smaller populations occupy at least nine smaller permanent villages.

Geography of the Copper River-Chugach Energy Region is dominated by the Wrangell, Saint Elias, and Chugach mountain ranges in the southern and western portions of the region and the Copper River and northwestern Gulf of Alaska basins in the central and southern portions of the region. The mainland along the northern Gulf of Alaska consists of alluvium- and glacier-covered coastal lowlands $0-25$ miles wide, backed by a belt up to 25 miles wide of rugged foothills rising to 6,600 feet (Plafker and others, 1994). These foothills are bordered to the north by the exceedingly rugged Chugach and Saint Elias mountains (Plafker and others, 1994). The geology of the region is dominated by three major crustal blocks commonly referred to by geologists as terranes. A terrane is a fault-bounded crustal block with geologic characteristics that are distinctly different from neighboring terranes. These terranes include the Yakutat, Wrangellia composite, and Southern Margin composite terranes which, through plate tectonic processes since Cretaceous time, were accreted to inboard terranes comprising the interior of Alaska. The Yakutat terrane is a thick sequence of Cenozoic clastic marine and nonmarine sedimentary rocks underlain partly by an offset fragment of the Chugach terrane and partly by Paleogene oceanic crust (Plafker and others, 1994). The Wrangellia composite terrane, composed of several smaller terranes, including the Peninsular, Alexander, and Wrangellia terranes, consists dominantly of Paleozoic- and Mesozoic-age arc-related magmatic and sedimentary rocks (Plafker and others, 1994). The Southern Margin composite terrane is composed of deep-marine rocks south of the Border Ranges fault and consists of the Chugach and Prince William terranes, the Ghost Rocks Formation and late Cenozoic accreted rocks (Plafker and others, 1994). Cenozoic-aged strata, which are most prospective for conventional and unconventional resources in this region, occur primarily in two sedimentary basins in the region (sheet 2). The northern Gulf of Alaska basin is largely offshore, but also includes sedimentary rocks exposed onshore near the coast. This basin includes a Cenozoic-age sedimentary succession between 9,800 and 16,400 feet thick; outcrops are scattered throughout the region, including Prince William Sound, Cordova, and east of the Copper River delta along the northern Pacific coast east of the sound (Kirschner, 1988). This basin developed on older rocks of the Yakutat and Southern Margin composite terranes. The Copper River basin, where there has been recent interest in oil and gas exploration, contains Cenozoic sediments between 0 and 9,800 feet thick (Kirschner, 1988). This basin is underlain by Paleozoic- and Mesozoic-age rocks of the Wrangellia composite terrane.

\section{GEOLOGIC ENERGY RESOURCE POTENTIAL IN THE COPPER RIVER- CHUGACH ENERGY REGION \\ Mineable coal resource potential}

Coal resources in the Copper River-Chugach Energy Region occur mostly in the Bering coal field (fig. E2), where coal has a relatively high rank and bed thicknesses can reach tens of feet. The Bering River coal field is located along the tributaries to the Bering River approximately 12 to 25 miles inland of Controller Bay, and approximately 35 miles to the east of the mouth of the Copper River. The field encompasses about 70-80 square miles with an estimated 160 million short tons of identified resources, and 3.5 billion short tons of hypothetical resources (Merritt, 1988). Coal resources in the Bering River field are concentrated at Carbon Creek, Trout Creek/Clear Creek/Cunningham Ridge, and Carbon Mountain (fig. E2). Coal-bearing strata occur in MiddleLate Eocene- to Early Oligocene-age Kushtaka Formation strata (Martin, 1908; Wolfe, 1977), subsequently mapped as Kulthieth Formation by Winkler and Plafker (1993). Coals in these rocks range in rank from subbituminous in the western part of the field to anthracite in the eastern region, and thus on average have relatively high heating values, averaging around $14,000 \mathrm{Btu}$, with medium ash and sulfur contents. Coal in the Bering River field may be best represented in the Carbon Creek area, where beds commonly occur in thicknesses of 5 to 10 feet, with some seams 30 to 60 feet thick (Merritt, 1988). Some coal beds are laterally discontinuous and sheared due to local folding and faulting. Although this structural complexity would inhibit successful mining, other areas in the field exhibit continuous coal beds for two or more miles (Martin, 1908).

Other known coal deposits in the Copper River-Chugach Energy Region are principally small, scattered occurrences of probable Eocene- to Miocene-age lignite exposed on the flanks of the Nutzotin and Wrangell mountains and southern foothills of the Alaska Range. Lignite exposures of limited aerial extent are reported to occur in tributaries to Beaver and Rocker creeks on the northeast flank of the Nutzotin Mountains, near the international border with Canada (Capps, 1915), an area that is also near the boundary with the Yukon-Koyukuk-Upper Tanana development region. Lignite also occurs on the southern flank of the Wrangell Mountains northeast of McCarthy near the head of the Chitistone River (Moffit and Knopf, 1910), and perhaps the head of Chisana Glacier (Merritt and Hawley, 1986) in the Wrangell-St. Elias Wilderness area, and to the southwest of Kennicott Glacier (Henning and Dobey, 1973; Merritt and Hawley, 1986). Henning and Dobey (1973) considered this entire area to be of low coal potential, although little is known about the coal resources in each of these areas.

The potential for mineable coal resources along the southern foothills of the eastern Alaska Range is poorly known. Coals in this area are from the Eocene-age Gakona 


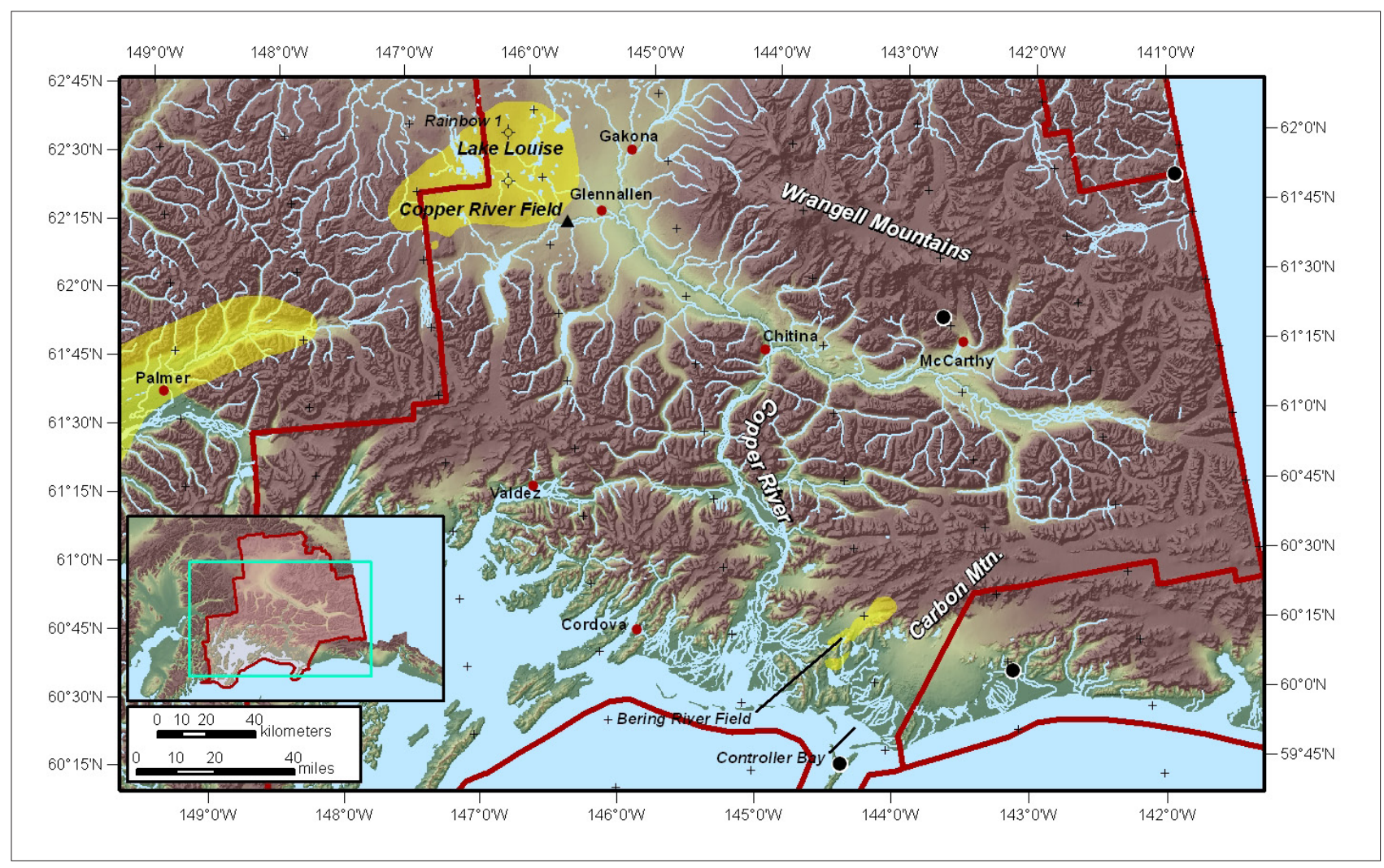

Figure E2. Location map of the Copper River-Chugach Energy Region, showing selected geographic references noted in the text. The black triangle indicates the location of the methane-emitting Tolsona group of mud volcanoes; black dots indicate reported coal occurrences; yellow-shaded areas are inferred to be underlain by coal-bearing rocks.

Formation (Mendenhall, 1905), and are also lignite in rank. Beds are reportedly up to 30 inches thick, but are likely of limited lateral extent (Moffit, 1954). Principal exposures occur near the range front along the Delta, Gulkana, Gakona, and Chisana river drainages (Moffit, 1954), although lignite beds presumably continue into the subsurface for some distance southward into the Copper River basin (sheet 2; fig. E2). A number of oil and gas exploration wells drilled in the Copper River basin have encountered lignite seams. Shallow Tertiary sedimentary rocks in the Salmonberry No. 1 and Rainbow No. 1 wells contain low-rank coal in individual seams up to 30 feet thick, and at depths of between 700 and 2,000 feet (Crick and Lian, 1970). Near Lake Louise, the lignite is near the surface and has been encountered at shallow depths in water wells drilled in the area (J. Clough, oral commun., 2012). In the middle of the Copper River basin, Merritt and Hawley (1986) depict a poorly constrained, but sizable lignite field in Miocene-age sediments in the Lake Louise area (fig. E2).

\section{Conventional oil and gas resource potential}

As explained in the discussion of requirements for exploitable oil and gas resources (see Chapter A), functioning petroleum systems occur in thick sedimentary basins, and consist of three basic elements: effective source rocks, reservoirs, and traps. Each of the elements must be in existence and connected at the time hydrocarbons are generated. This section considers each of these necessary elements of petroleum systems in turn to evaluate whether conventional oil and gas resources may play a role in supplying rural energy in the Copper River-Chugach Energy Region.

Overview of sedimentary basins. Sedimentary basins that may be capable of sustaining effective petroleum systems in the Copper River-Chugach region include the Copper River basin and the northwestern part of the Gulf of Alaska basin (sheet 2; fig. E2). Neither basin currently supports commercial oil or gas production, but recent gas exploration has been undertaken in the Copper River basin, and the Katalla oil field in the northern Gulf of Alaska basin was the site of shallow, small-scale commercial oil production from 1902 to 1932 . These two sedimentary basins are entirely separate from each other and were formed at different times in response to the plate tectonic processes that assembled numerous different crustal blocks or terranes to form the complex geologic mosaic of southern Alaska. Other parts of the Copper River-Chugach Energy Region are underlain by igneous, metamorphic, or thermally overmature sedimentary 
rocks that are incapable of hosting exploitable accumulations of oil and gas.

The Copper River basin includes Cenozoic strata less than about 65 million years old that reach thicknesses of up to approximately 1 kilometer (sheet 2; Kirschner, 1988, 1994). These younger strata overlie older Mesozoic formations of the Peninsular terrane that are closely related to Mesozoic rocks of the Alaska Peninsula and Cook Inlet. These older rocks were originally deposited in ancestral basins south of their present location, and were slowly transported long distances northward by plate tectonic processes and ultimately sutured onto the previously assembled blocks of what is now interior Alaska (Silberling and others, 1992; Plafker and others, 1994).

In contrast, the Gulf of Alaska sedimentary basin (sheet 2) consists entirely of Cenozoic formations on Alaska's presentday southern continental margin. The most prospective lands for oil and gas exploration belong to the Yakutat terrane, a crustal block composed of Cenozoic sedimentary units up to 9 kilometers thick deposited on slightly older Cenozoic and Mesozoic basement. Geologic and paleomagnetic evidence indicate that the Yakutat block originated approximately 50 million years ago near the present-day coast of British Columbia, 1,100 to 1,800 kilometers south of its current position (Risley and others, 1992). Since then, plate tectonic processes have transported the Yakutat block north along the western edge of North America, resulting in collisional deformation and mountain building in southern Alaska that continues into modern times.

Source rocks. The hydrocarbon potential in the Copper River basin is likely gas. Of the 13 exploration holes drilled in the basin to date, a few of the easternmost wells have encountered mudlog shows of methane gas, but none reported significant indications of oil. Gases seeping from the Tolsona group of mud volcanoes and saline springs in the western part of the basin (fig. E2) contain methane in varying amounts ranging from $<1$ percent to more than 72 percent, in addition to noncombustible gases such as carbon dioxide and nitrogen (Motyka and others, 1986). Carbon isotopic signatures of nearly all the methane from these seeps suggest it is sourced from thermogenic and biogenic alteration of coal and lignite beds in late Mesozoic to early Cenozoic nonmarine units in the basin (Reitsema, 1979).

The Tuxedni Formation, the Mesozoic source rock for most of the oil in Cook Inlet reservoirs, is also present in the Copper River basin, but it is sandy and apparently not as oil-prone (Magoon and Valin, 1996). Several wells have encountered overpressured Mesozoic formations at depth that contain saline formation waters charged with methane. These subsurface units are believed to be hydraulically connected with some of the mud volcanoes and saline springs at the surface (Motyka and others, 1986). The two most recent wells drilled in the basin were on private Ahtna Native Corporation lands, so complete information is not publicly available, but reports of high-pressure gas-bearing zones suggest that follow-up work may be warranted (Petroleum News, 2007). Limited thermal maturity information for the Copper River basin indicates a relatively low geothermal gradient (Motyka and others, 1986), and with the exception of the Wrangell Mountains volcanic field on the basin's eastern edge, the petroleum generation window likely lies at depths below 8,000 feet (Magoon and Valin, 1996). Therefore, given the basin's limited thickness, most of the basin is immature to only marginally mature for oil and gas generation (Utah International, Inc., 1987; DGSI, 1995; unknown, 1995b, 1995c). This interpretation is further evidenced by the scarcity of significant shows encountered during drilling, and it remains unclear whether the Copper River basin has generated appreciable quantities of either biogenic or thermogenic hydrocarbons.

As noted above, the western segment of the Gulf of Alaska basin is the other area of oil and gas interest in the Copper River-Chugach Energy Region. The greatest petroleum potential is within the onshore portion of the Yakuta terrane; the crustal blocks of the Chugach Range and Prince William Sound to the north and west are devoid of source rocks and, for the most part, are thermally overmature. In the Katalla area, on the northwestern edge of the Yakutat block, natural oil and gas seeps and historic oil production from a shallow, fractured shale reservoir point to a petroleum system with moderate potential. Source rocks for onshore oil and gas seeps in the northern Gulf of Alaska region include shales of the Poul Creek Formation and coals of the Kulthieth Formation (Risley and others, 1992; Magoon 1994; Larson and Martin, 1998; Van Kooten and others, 2002). In the Katalla area, these source rocks range from early mature to overmature for hydrocarbon generation (Mull and Nelson, 1986).

Reservoir rocks. There is relatively little data available from the Copper River basin to estimate the subsurface extent of formations with sufficient porosity and permeability to serve as conventional oil or gas reservoirs. Published resource assessments invoke upper Mesozoic to lower Cenozoic sandstones as the most likely reservoirs (Magoon and Valin, 1996). These formations are near the top of the basin's stratigraphic succession, where it is thought they may have retained more porosity and permeability than older units buried to greater depths. The slightly older and overpressured Nelchina Formation has been targeted as a gas reservoir by recent drilling (Petroleum News, 2007), and further drill stem tests and other reservoir evaluation techniques will be required to determine whether this unit will be capable of sustained hydrocarbon production.

In the Gulf of Alaska basin, potential conventional reservoir rocks are restricted to the Yakutat block; other terranes are made up of highly altered formations with insufficient porosity and permeability. Reservoir candidates in the Yakutat terrane include wave-reworked sandstones of 
the upper Cenozoic Yakataga Formation, local sandstones in the upper part of the mid-Cenozoic Poul Creek Formation, and nonmarine to deltaic sandstones of the lower Cenozoic Kulthieth and Tokun Formations (Risley and others, 1992; Larson and Martin, 1998). In the part of the Gulf of Alaska basin in the Copper River-Chugach Energy Region, the reservoir quality of these formations is variable. The Yakataga Formation consists of poorly sorted glaciomarine beds with unstable mineralogy, but is known to maintain local zones of good porosity and permeability at depths below 11,000 feet in offshore wells (Larson and Martin, 1998). The Kulthieth Formation contains abundant sandstone with poor to moderate reservoir properties farther east in the Southeast Energy Region, but in the Copper River-Chugach Energy Region, it consists almost exclusively of fine-grained, non-reservoir rocks (or perhaps unconventional reservoirs). Finally, only locally does the Poul Creek Formation contain potential reservoir sandstones; it consists in large part of highly deformed silty to shaly rocks like those hosting the oil seeps and shallow fractured reservoir at Katalla. On the favorable side, the Kulthieth and Poul Creek Formations have the advantage that they also contain source rocks, increasing the likelihood that any potential reservoir sandstones may have received hydrocarbon charge.

Traps. Both the Copper River basin and the northern Gulf of Alaska basin have been strongly affected by faulting and folding accompanying compressional and strike-slip tectonics, creating numerous fold and fault structures that have the potential to trap hydrocarbons. Additional traps may be stratigraphic in nature, established by lateral variations in thickness, grain size, permeability, and other sedimentary characteristics inherent in these geologically complex settings. However, repetitive deformation commonly forms complicated structures that can create exploration and development challenges and limit accumulation sizes. Although several structures in the Gulf of Alaska were unsuccessfully tested by exploration wells, many promising and large structures remain undrilled (Risley and others, 1992).

Summary of conventional oil and gas resource potential. Only a limited number of exploration wells have been drilled in the Copper River basin, yet none have resulted in commercial discoveries. Although oil potential appears to be low (Magoon and others, 1996), natural gas seeps and significant gas shows during exploration drilling suggest the area has some potential to host a functional petroleum system. Available subsurface data are sparse and more information is required to reliably assess the basins potential (Thomas and others, 2004).

Major seeps of both oil and gas are present on the northern margin of the Yakutat terrane, indicating that the northern Gulf of Alaska basin does contain a viable petroleum system. Despite the lack of any commercial discoveries to date, potential remains for future production of conventional hydrocarbons. Many large structural and stratigraphic traps likely remain undrilled and the province is underexplored relative to comparable oil-bearing basins in North America. The most recent available estimates of technically recoverable resources from the Gulf of Alaska region report a mean value of 630 million barrels of oil and 4.65 trillion cubic feet of natural gas (MMS, 2006a, 2006b). These numbers reflect undiscovered, hypothetical resources that have not been confirmed by drilling, and the actual amount that could be discovered and produced may be significantly smaller when filtered against the high costs of offshore development. Nevertheless, the large estimates reflect the overall promising nature of the region for future hydrocarbon exploration.

\section{Unconventional oil and gas resource potential}

Coalbed methane. The most significant known coal resources in the Copper River-Chugach Energy Region primarily occurs in the Bering River coal field, where coal-bearing strata are common in the Paleogene Kushtaka Formation (Kulthieth Formation). In the Carbon Creek area of the field, coal seams are commonly 5 to 10 feet thick, with seams locally ranging up to 30 to 60 feet thick. Coal rank ranges from subbituminous to anthracite and is of sufficient grade to produce coalbed methane. However, many of the coal-bearing strata are part of a regional fold and thrust belt and coals are locally laterally discontinuous due to stratigraphic pinch-out or structural truncation. The structural complexity of high-rank coals in the Bering River field would present a challenge to effective production of significant coalbed methane resources. Other known coal deposits in the region consist of small, scattered exposures of lignite along the foothills of the Alaska Range and in the Copper River Basin. The reported low maturity of these coals indicate they are unlikely to have natural fractures (cleats) that are necessary for successful coalbed methane production.

Tight gas sands. Published data suggest upper Mesozoic and lower Cenozoic sandstones are likely to form conventional reservoirs capable of producing some hydrocarbons in the Copper River-Chugach Energy Region. Many of the Mesozoic sandstones in the Copper River region, in particular the Nelchina, Staniukovich, and Naknek Formations, have been relatively deeply buried and have undergone significant compaction and cementation. If these units were sufficiently charged from nearby source rocks, they may serve as potential tight gas reservoirs. Extensive regional fractures have been observed in outcrops of some of the Mesozoic sandstones, particularly the Naknek Formation. These fractures are typical of tight gas sands and may well signal the presence of an unconventional, fractured reservoir.

In the Gulf of Alaska region, the Eocene Kulthieth Formation may locally have potential as a tight gas sand. It consists of relatively thick nonmarine to deltaic sandstones with variable reservoir quality. While much of the unit has fair 
to good porosity, zeolite cements (particularly laumontite) have locally degraded reservoir quality to the extent that sands have permeabilities less than 0.01 millidarcy. Potential source rocks in the lower part of the Kulthieth Formation consist of gas-prone shallow marine deltaic to basinal marine sediments (Plafker and others, 1994) that could act as an intra-formational source. Local fractures have been observed in thin sections of the Kulthieth Formation (ARCO White Lake \#1) and may signal the existence of a more regionally extensive fracture system necessary for an effective unconventional, fractured reservoir. The ARCO OCS Y-0211 (Yakutat No. 1) well encountered significant oil and gas shows in the Kulthieth sandstones.

Shale gas. One of the primary requirements for shale gas is an organic-rich source rock present in the thermogenic gas window that is sufficiently brittle to host a natural fracture system (see Chapter A). Data from the Copper River basin are sparse, but the scarcity of significant hydrocarbon shows in exploration wells suggest that significant quantities of thermogenic hydrocarbons may never have been generated. However, important aspects of the subsurface of this basin remain unknown. In the Katalla area of the Gulf of Alaska, basin shales of the Poul Creek and Kulthieth Formations are potential source rocks for both oil and gas. Furthermore, most of the observed seeps in the region are believed to be intraformational, indicating that naturally fractured source rocks were capable of generating and storing hydrocarbons.

Gas hydrates. The main occurrences of gas hydrates in nature are in modern marine sediments and in arctic regions with well developed, continuous permafrost. Permafrost is not well developed in the Copper River-Chugach Energy Region, and where locally present is discontinuous. Consequently, the potential is low for economic concentrations of gas hydrates.

\section{Geothermal resource potential}

Geothermal prospectivity in the Copper River-Chugach Energy Region is limited to the immediate vicinity of Glennallen and western portions of the Wrangell Mountains. Three occurrences of thermal spring temperatures above $60^{\circ} \mathrm{F}$ $\left(16^{\circ} \mathrm{C}\right)$ have been measured in the region. By comparison, 12 occurrences of thermal springs with temperatures above $165^{\circ} \mathrm{F}\left(74^{\circ} \mathrm{C}\right)$ have been measured in the Aleutian region and three occurrences above $165^{\circ} \mathrm{F}\left(74^{\circ} \mathrm{C}\right)$ have been measured in the Southeast region (Motyka and others, 1983).

Two groups of mud volcanoes are located near Glennallen. The Klawasi group, east of Glennallen, has slightly warmer waters and considerably more carbon dioxide gas than the Tolsona group west of Glennallen (Motyka and others, 1983). Both groups discharge highly saline waters thought to originate from a zone of overpressured Cretaceous-age marine sedimentary rocks underlying the Copper River basin (Motyka and others, 1983; Motyka and others, 1986). The proximity of the Klawasi group to the Quaternary volcanoes in the western Wrangell Mountains has led to speculation that a geothermal resource underlies the mud volcanoes and acts as the source of the measured carbon dioxide gas (Motyka and others, 1983). The source of the methane measured in the Tolsona group, and to a lesser extent in the Klawasi group, is likely coal beds in the Cretaceous formations underlying the basin; however, the particularly heavy isotopic signatures for the methane gas at the Klawasi mud volcanoes infers a mantle component, suggesting a potential geothermal source (Motyka and others, 1986). Geothermometers applied to the Klawasi spring waters are inconclusive, with some suggesting a cold-water source and others indicating temperatures higher than $302^{\circ} \mathrm{F}\left(150^{\circ} \mathrm{C}\right)$ (Motyka and others, 1983). The Copper River-Chugach region contains one fumarolic field near the north summit crater of Mount Wrangell with measured temperatures as high as $187^{\circ} \mathrm{F}\left(86^{\circ} \mathrm{C}\right)$ (Motyka and others, 1983).

When considered as a whole, the Copper River-Chugach Energy Region contains only a limited number of geothermal manifestations, all of which are inside the Wrangell-Saint Elias National Park and Preserve boundary. Of the three thermal springs in the region, none are at surface temperatures $>100^{\circ} \mathrm{F}\left(38^{\circ} \mathrm{C}\right)$.

\section{RECOMMENDATIONS \\ Unconventional oil and gas resource recommendations}

Coalbed methane. Due to the limited areal extent and structural complexity of the Bering River coal field, the volume of accessible coal does not appear sufficient to produce commercial quantities of coalbed methane. Available data from the Copper River basin area suggest most coals are thin and insufficiently mature to serve as viable coalbed methane reservoirs. However, these coals are poorly understood and may warrant additional reconnaissance geologic investigation prior to discounting their potential completely.

Tight gas sands. Available data suggest that Mesozoic sandstones in the Copper River region may possess either matrix or fractured reservoir quality sufficient to host a tight gas accumulations. Similarly, Eocene-age sandstones in the Gulf of Alaska region may have local potential as an unconventional reservoir. This type of resource play has not been targeted in this frontier region, and more geologic data would be required to reduce exploration risk. Development of tight gas sandstones in this setting typically requires a high density of wells and artificial stimulation, both of which add significantly to exploration and development costs, challenging economic viability.

Shale gas. Insufficient data are available to reliably assess the potential for shale gas in the deeper parts of the Copper River basin. However, available information suggests that few, if any, source rocks have reached the thermogenic gas window. Subsurface data on source rock quality and maturity would be required to further evaluate 
the basin's potential for shale gas. Shales of the Poul Creek and Kulthieth Formations in the Gulf of Alaska region have some potential as a resource play, particularly in the fold and thrust belt where a significant natural fracture system may be present. Additional geologic information could improve assessments of this play, including data on the distribution of source rock quality and thermal maturity. However, the economic feasibility of this type of development in a frontier region would be challenging; unconventional resource plays typically produce relatively small amounts of hydrocarbons from each well and profitability depends on inexpensive drilling costs.

Gas hydrates. Due to the lack of extensive, continuous permafrost in most of the Copper River basin, the likelihood of finding gas hydrates in the region are very low, therefore no further action is recommended.

\section{Conventional oil and gas resource recommendations}

The locations of rural communities in the Copper River-Chugach Energy Area are largely on the road system, and patterns of land ownership are important considerations in weighing the state's options for oil and gas energy development for local use in the Copper River-Chugach Energy Region. The sparse drilling record in the Copper River basin has not discovered any commercial hydrocarbons, but did locally record shows of natural gas. The ultimate potential of the basin remains poorly known. A more robust understanding of the hydrocarbon potential could be developed via additional geologic field studies along the basin margins. However, evaluation of the prospective subsurface part of the basin would require new, modern seismic data, followed by targeted exploration drilling.

Major seeps of both oil and gas are present on the northern Gulf of Alaska east of the Copper River delta. Despite the lack of any commercial discoveries to date, many large structural and stratigraphic traps remain undrilled, and there is still potential for future production and potential remains for future production of conventional hydrocarbons. The available data suggest the region warrants additional investigation, including onshore geologic mapping and the collection of modern seismic data. Although this region may ultimately yield commercial hydrocarbon discoveries, there are no communities in close enough proximity to this prospective resource to be able to directly utilize it for local energy.

\section{Coal resource recommendations}

The generally limited thickness and low thermal maturity of coals surrounding the Copper River basin do not appear to warrant additional consideration as a viable local energy source. However, many of the reported occurrences have not been studied in detail, and further geological evaluation could improve knowledge of the distribution and character of any potential coal resources. The Bering River field includes high-quality coal, but may be complicated by local structure - a characteristic that led Alaska Division of Energy \& Power Development (1977) to rank the field low on a list of future developable coal fields. Nevertheless, the region has witnessed very few detailed geologic studies, and a reliable assessment of the potential coal resources would require further mapping and focused stratigraphic and structural studies.

\section{Geothermal resource recommendations}

There are only limited possibilities for developable geothermal resources in the Copper River-Chugach Energy Region. The most promising geothermal features are in the Wrangell-Saint Elias National Park and Preserve boundary and are thus currently unavailable for geothermal development. The Tolsona mud volcanoes, while located outside the National Park and Preserve boundary, produce cool surface discharge temperatures $\left(50^{\circ} \mathrm{F}\left[10^{\circ} \mathrm{C}\right]\right)$ and isotopic analysis performed on Tolsona mud volcano gases suggests a coal and lignite source rather than a magmatic source. For these reasons, Tolsona shows little potential for a viable geothermal application. Because of limited geothermal manifestations and land ownership issues, no further investigation is warranted at this time.

\section{REFERENCES CITED AND \\ SELECTED BIBLIOGRAPHY}

Alaska Division of Energy and Power Development, 1977, Alaska regional energy resources planning project, phase I-Alaska's energy resources findings and analysis, final report, v. I of XI, p. 93-97.

Alaska Energy Authority (AEA), 2009, Alaska energy-A first step toward energy independence: Alaska Energy Authority, 245 pages. Available online at http://www. akenergyauthority.org/pdf files/AK Energy Final.pdf (accessed November 12, 2009).

Barnes, F.F., 1951, A review of the geology and coal resources of the Bering River coal field, Alaska: U.S. Geological Survey Circular 146, $11 \mathrm{p}$.

Beikman, H.M., 1980, Geologic map of Alaska: U.S. Geological Survey special map, 1 sheet, scale 1:2,500,000.

Bruns, T.R., 1996, Gulf of Alaska, in Gautier, D.L., Dolton, G.L., Takahashi K.I., and Varnes, K.L., eds., 1995 national assessment of United States oil and gas resourcesResults, methodology, and supporting data, U.S. Geological Survey Digital Data Series DDS-30, CD-ROM.

Capps, S.R., 1915, Mineral resources of the Chisana-White River district, in U.S. Geological Survey Staff, eds., Mineral resources of Alaska; Report on progress of investigations in 1914: U.S. Geological Survey Bulletin 622, p. 189-228.

Crick, R.W., and Lian, E.R., 1970, Copper River basin stratigraphic sections, Tawawe Lake to Moose Creek and 
Eureka to Rainbow: Anchorage, Alaska, Alaska Geological Society, 2 plates.

DGSI, 1995, Organic carbon, rock-eval pyrolysis, and visual kerogen data from cuttings of the following Copper River basin oil and gas exploratory wells_-Aledo Oil Co. Eureka \#2 (2,000-8,545 ft); and Mobil Oil Corp. Salmonberry Lake Unit \#2 (1,500-7,900 ft): Alaska Division of Geological \& Geophysical Surveys Geologic Materials Center Data Report No. 248, 10 p.

Fuis, G.S., Moore, T.E., Plafker, George, Brocher, T.M., Fisher, M.A., Mooney, W.D., Nokleberg, W.J., Page, R.A., Beaudoin, B.D., Christensen, N.I., Levander, A.R., Lutter, W.J., Saltus, R.W., and Ruppert, N.A., 2008, Trans-Alaska Crustal Transect and continental evolution involving subduction underplating and synchronous foreland thrusting: Geology, v. 36, p. 267-270.

Geochron Laboratories, Inc., 1995, Potassium-argon whole rock age determinations of core samples from the following Copper River basin oil and gas wells-Eureka \#2, Ahtna Inc. and Salmonberry Lake Unit \#1: Alaska Division of Geological \& Geophysical Surveys Geologic Materials Center Data Report No. 247, 7 p.

Henning, M.W., and Dobey, P.L., 1973, Geologic and mineral evaluation of the Chitina and Bremner River drainage basins: Alaska Division of Geological \& Geophysical Surveys Alaska Open-File Report 25, 25 p., 1 sheet, scale 1:250,000.

Johnsson, M.J., and Howell, D.G., eds., 1996, Thermal evolution of sedimentary basins in Alaska: U.S. Geological Survey Bulletin 2142, 131 p., 1 sheet, scale 1:2,500,000.

Kirschner, C.E., 1988, Map showing sedimentary basins of onshore and continental shelf areas, Alaska: U.S. Geological Survey Miscellaneous Investigations Series Map 1873, 1 sheet, scale 1:2,500,000.

1994, Interior basins of Alaska, in Plafker, George, and Berg, H.C., eds., The Geology of Alaska: Boulder, Colorado, Geological Society of America, The Geology of North America, v. G-1, p. 469-493.

Larson, John, and Martin, Gary, 1998, Gulf of Alaska shelf assessment province, in Sherwood, K.W., ed., Undiscovered oil and gas resources, Alaska federal offshore: U.S. Minerals Management Service OCS Monograph MMS 98-0054, p. 301-305.

Lyle, W.M., and Palmer, I.F., Jr., 1976, Stratigraphic study of the Gulf of Alaska Tertiary province, northern Gulf of Alaska area: Alaska Division of Geological \& Geophysical Surveys Alaska Open-File Report 93, 173 p., 23 sheets, scale 1:63,360.

Magoon, L.B., III, 1994, Petroleum resources in Alaska, in Plafker, George, and Berg, H.C., eds., The Geology of Alaska: Boulder, Colorado, Geological Society of America, The Geology of North America, v. G-1, p. 905-936.

Magoon, L.B., III, and Valin, Z.C., 1996, Copper River basin, in Gautier, D.L., Dolton, G.L., Takahashi K.I., and
Varnes, K.L., eds., 1995 national assessment of United States oil and gas resources - results, methodology, and supporting data, U.S. Geological Survey Digital Data Series DDS-30, CD-ROM.

Martin, G.C., 1905; The petroleum fields of the Pacific Coast of Alaska, with an account of the Bering River coal deposits: U.S. Geological Survey Bulletin 250, 64 p.

1921, Preliminary report on petroleum in Alaska: U.S. Geological Survey Bulletin 719, 83 p., 5 sheets, scale 1:125,000.

McGee, D.L., 1973, Gulf of Alaska petroleum seeps: Alaska Division of Geological \& Geophysical Surveys Alaska Open File Report 32, 7 p.

Mendenhall, W.C., 1905, Geology of the central Copper River region, Alaska: U.S. Geological Survey Professional Paper 41, 133 p., 4 sheets, scale 1:250,000.

Merritt, R.D., 1986, Alaska-Coal fields and seams 1987: Alaska Division of Geological \& Geophysical Surveys Public Data File 86-90, 55 p.

1988, Alaska bituminous coal and anthracite: Alaska Division of Geological \& Geophysical Surveys Public Data File 88-15, 116 p.

Merritt, R.D., and Hawley, C.C., 1986, Map of Alaska's coal resources: Alaska Division of Geological \& Geophysical Surveys Special Report 37, 1 sheet, scale 1:2,500,000.

Meyer, J.F., Jr., 2008, Oil and gas basin resource series for maps of Interior Alaska-Copper River basin, Holitna basin, Minchumina basin, Nenana basin, and Susitna basin: Alaska Division of Oil \& Gas Basin Resource Series, 24 plates, scale 1:250,000 and 1:1,000,000.

Miller, D.J., 1951, Preliminary report on the geology and oil possibilities of the Katalla District, Alaska: U.S. Geological Survey Open-File Report 51-20, 66 p., 4 sheets, scale 1:96,000.

1975, Geologic map and sections of central part of the Katalla District, Alaska: U.S. Geological Survey Miscellaneous Field Studies 722, 2 sheets, scale 1:40,000.

Miller, D.J., Payne, T.G., and Gryc, George, 1959, Geology of possible petroleum provinces in Alaska: U.S. Geological Survey Bulletin 1094, 131 p., 4 sheets, scale 1:2,500,000.

Minerals Management Service (MMS), 2006a, Undiscovered Oil and Gas Resources, Alaska Federal Offshore: U.S. Department of the Interior Minerals Management Service Alaska OCS Region.

Minerals Management Service (MMS), 2006b, Planning area resources addendum to assessment of undiscovered technically recoverable oil and gas resources of the nation's Outer Continental Shelf, 2006: U.S. Minerals Management Service, Fact Sheet, http://www.boemre.gov/ revaldiv/PDFs/NA2006BrochurePlanningArealnsert.pdf.

Moffit, F.H., 1954, Geology of the eastern part of the Alaska Range and adjacent area: U.S. Geological Survey Bulletin 989-D, p. 63-218, 2 sheets, scale 1:250,000. 
Moffit, F.H., and Knopf, Adolph, 1910, Mineral resources of the Nabesna-White River district, Alaska: U.S. Geological Survey Bulletin 417, 64 p., 2 sheets, scale 1:250,000.

Motyka, R.J., Hawkins, D.B., Poreda, R.J., and Jeffries, A., 1986, Geochemistry, isotopic composition, and the origin of fluids emanating from mud volcanoes in the Copper River basin, Alaska: Alaska Division of Geological \& Geophysical Surveys Public Data File 86-34, 87 p.

Motyka, R.J., Moorman, M.A., and Liss, S.A., 1983, Geothermal resources of Alaska: Alaska Division of Geological \& Geophysical Surveys Miscellaneous Publication 8, 1 sheet, scale 1:2,500,000.

Mull, C.G., and Nelson, S.W., 1986, Anomalous thermal maturity data from the Orca Group (Paleocene and Eocene), Katalla-Kayak Island area, in Bartsch-Winkler, S., and Reed, K.M., eds., Geologic studies in Alaska by the U.S. Geological Survey during 1985: U.S. Geological Survey Circular 978, p. 50-55.

Nichols, D.R., and Yehle, L.A., 1961, Analyses of gas and water from two mineral springs in the Copper River basin, Alaska: U.S. Geological Survey Professional Paper 424-D, p. D191-D194.

Petroleum News, 2007, Looks like a gas discovery: Petroleum News, v. 12, no. 26, p. 1, 18.

Plafker, George, Moore, J.C., and Winkler, G.R., 1994, Geology of the southern Alaska margin, in Plafker, George, and Berg, H.C., eds., The Geology of Alaska: Boulder, Colorado, Geological Society of America, The Geology of North America, v. G-1, p. 389-449.

Reitsema, R.H., 1979, Gases of the mud volcanoes in the Copper River basin, Alaska: Geochimica et Cosmochimica Acta, v. 43, p. 183-187.

Risley, D.E., Martin, G.C., Larson, J.A., Lynch, M.B., Flett, T.F., and Horowitz, W.L., 1992, Geologic report for the Gulf of Alaska Planning Area, in Turner, R.F., ed.,: U.S. Minerals Management Service OCS Report MMS 92-0065, 302 p., 9 appendices, 6 plates.

Silberling, N.J., Jones, D.L., Monger, J.W.H., and Coney, P.J., 1992, Lithotectonic terrane map of the North American Cordillera: U.S. Geological Survey Miscellaneous Investigations Series Map I-2176, 2 sheets, scale 1:5,000,000.

Thomas, C.P., Doughty, T.C., Faulder, D.D., and Hite, D.M., 2004, South-central Alaska natural gas study: U.S. Department of Energy, National Energy Technology Laboratory Arctic Energy Office, http://fossil.energy. gov/programs/oilgas/publications/naturalgas_general/ southcentralalaska_study.pdf.

Trop, J.M., and Plawman, T.L., 2006, Bedrock geology of the Glen Highway from Anchorage to Sheep Mountain, Alaska-Mesozoic-Cenozoic forearc basin development along an accretionary convergent margin: Field trip guidebook, May 2006 Joint Meeting of the Geological Society of America (Cordilleran Section), American As- sociation of Petroleum Geologists (Pacific Section), and Society of Petroleum Engineers (Western Region), 20 p.

Trop, J.M., Szuch, D.A., Rioux, M., and Blodgett, R.B., 2005, Sedimentology and provenance of the Upper Jurassic Naknek Formation, Talkeetna Mountains, Alaska-Bearings on the accretionary tectonic history of the Wrangellia composite terrane: Geological Society of America Bulletin v. 117 , p. 570-588.

Troutman, S.M., and Stanley, R.G., 2003, Maps showing sedimentary basins, surface thermal maturity, and indications of petroleum in the central Alaska province: U.S. Geological Survey Miscellaneous Field Studies 2428, 20 p., 2 sheets, scale 1:2,500,000, http://pubs.usgs.gov/ $\mathrm{mf} / 2003 / 2428 /$.

Unknown, 1995a, Chronostratigraphic summaries based on palynological content of cuttings from the following Copper River Basin oil and gas exploratory wells-Eureka \#2, Ahtna Inc. \#1, Salmonberry Lake Unit \#1, Moose Creek Unit \#1 and Tazlina \#1: Alaska Division of Geological \& Geophysical Surveys Geologic Materials Center Data Report No. 250, 7 p.

Unknown, 1995b, Source rock geochemical and visual kerogen data from cuttings of the following Copper River Basin oil and gas exploratory wells-Amoco Production Company Ahtna Inc. \#1 (2,000-7,928 ft); and Pan American Moose Creek Unit \#1 (1,980-7,860 ft): Alaska Division of Geological \& Geophysical Surveys Geologic Materials Center Data Report No. 253, 6 p.

Unknown, 1995c, Source rock geochemical and visual kerogen data from cuttings $(2,520-8,837 \mathrm{ft})$ of the Union Oil Company of California Tazlina \#1 well: Alaska Division of Geological \& Geophysical Surveys Geologic Materials Center Data Report No. 249, 5 p.

Utah International, Inc., 1987, Vitrinite reflectance measurement of cuttings and coal outcrops from Alaska: Alaska Division of Geological \& Geophysical Surveys Geologic Materials Center Data Report No. 67, 56 p.

Van Kooten, G.K., Short, J.W., and Kolak, J.J., 2002, Lowmaturity Kulthieth Formation coal-A possible source of polycyclic aromatic hydrocarbons in benthic sediment of the northern Gulf of Alaska: Environmental Forensics, v. 3, p. 227-241.

Wahrhaftig, Clyde, 1960, The physiographic provinces of Alaska: U.S. Geological Survey Open-File Report 60$146,76 \mathrm{p}$.

Winkler, G.R., and Plafker, George, 1993, Geologic map of the Cordova and Middleton Island quadrangles, southern Alaska: U.S. Geological Survey Miscellaneous Investigations 1984, 1 sheet, scale 1:250,000.

Wolfe, J.A., 1977, Paleogene floras from the Gulf of Alaska region: U.S. Geological Survey Professional Paper 997, $108 \mathrm{p}$. 